\title{
ANALISIS PROSEDUR BSM GADAI EMAS PERSPEKTIF SE BANK INDONESIA NO.14/7/DPbS DAN FATWA DSN MUI NO. 26/DSN-MUI/III/2002
}

\author{
Nidaul Izzah \\ Institut Ilmu Sosial dan Manajemen STIAMI \\ Filma Ginanjar Prasya
}

\begin{abstract}
ABSTRAK. Prosedur Analisis BSM Gadai (Rahn) Emas adalah di Kepatuhan dengan perspektif SE Bank Indonesia SE 14/7 / DPbS dan DSN MUI Fatwa No. 26 / DSN-MUI / III / 2002. BSM Gadai (Rahn) Emas adalah salah satu produk yang dimiliki oleh PT. Bank Syariah Mandiri. Sebuah lembaga keuangan perbankan yang bergerak sesuai dengan sistem syariah Islam. Produk ini sebelumnya telah dilakukan oleh beberapa lembaga dengan sendirinya dan ternyata bahwa gadai dijalankan dengan sistem konvensional. Oleh karena itu, Bank Syariah Mandiri sedang mencoba untuk mengadopsi janji ini menjadi salah satu itu adalah produk melalui BSM gadai (Rahn) emas sesuai dengan sistem syariah Islam.

Dalam menjalankan usahanya, Bank Syariah Mandiri memiliki aturan direferensikan oleh regulator yang Bank Indonesia sebagai regulator yang mengatur proses perbankan dan Majelis Ulama Indonesia (MUI) sebagai regulator yang mengatur aturan syariah Islam. Dalam melaksanakan setiap proses bisnis, Bank Syariah Mandiri harus memperhatikan dua regulator. Itulah alasan mengapa penulis merasakan kebutuhan untuk melakukan penelitian pada apakah prosedur BSM Gadai (Rahn) Emas memenuhi Bank Indonesia perspektif SE14 / 7 / DPbS dan DSN MUI Fatwa No.26 / DSN-MUI / III / 2002. Hal ini diperlukan agar penulis merasa yakin untuk dapat menjadi agen dalam mengembangkan ekonomi sesuai dengan sistem syariah Islam.

Dari hasil analisis penelitian ini, penulis menemukan bahwa kesesuaian produk BSM Gadai (Rahn) Emas dengan peraturan dari dua regulator. Hal ini diperoleh dari kuesioner yang diberikan kepada nasabah BSM Gadai (Rahn) Gold dan dari wawancara dengan karyawan Bank Syariah Mandiri sebagai penjual produk. Hasil ini juga dapat menjadi dasar dalam mempelajari penerapan sistem ekonomi syariah.
\end{abstract}

Kata kunci: Prosedur, Kesesuaian.

ABSTRACT. Procedure Analyze of BSm Pawning (Rahn) Gold is in Compliance with SE Bank Indonesia perspective SE 14/7/DPbS and DSN MUI Fatwa No. 26/DSN-MUI/III/2002. BSM Pawning (Rahn) Gold is one of the products owned by PT. Bank Syariah Mandiri. A banking financial institution engaged in accordance with Islamic sharia system. This product has previously been carried out by the several institution by it self and it turned out that pawning is executed with conventional systems. Therefore, Bank Syariah Mandiri is trying to adopt this pledge into one of it is products through BSM pawning (Rahn) gold in accordance with Islamic sharia system.

In conducting its business, Bank Syariah Mandiri has rules referenced by regulators which are Bank Indonesia as the regulator which regulates the banking processes and Majelis Ulama Indonesia (MUI) as the regulator of governing the rules of Islamic sharia. In carrying out any business process, Bank Syariah Mandiri should pay attention to the two regulators. That is the reason why the author feel the needs to conduct research on whether the procedure of BSM Pawning (Rahn) Gold is in compliance with Bank Indonesia perspective SE14/7/DPbS and DSN 
MUI Fatwa No.26/DSN-MUI/III/2002. This is necessary so that the authors feel confident to be able to become an agent in developing economy in accordance with Islamic sharia system.

From the results of the analysis of this study, the writer found that the suitability of the product BSM Pawn (Rahn) Gold with the regulations from the two regulators. It is obtained from the questionnaire given to the customers of BSM Pawning (Rahn) Gold and from the interviews with employees of Bank Syariah Mandiri as the seller of the product. These results can also be the basis in learning the implementation of sharia economic system.

Key words: Procedure, Suitability.

\section{PENDAHULUAN}

Keberadaan lembaga yang membidangi usaha gadai sudah tidak asing lagi.Bahkan lembaga ini menjadi sangat popular di kalangan masyarakat Indonesia khususnya masyarakat Jakarta.Lembaga gadai ini memang sangat membantu masyarakat terutuma pada saat menjelang lebaran dan tahun ajaran baru. Hal ini dikarenakan kebutuhan dana yang cukup besar sedangkan kepemilikan dana yang dimiliki sangatlah terbatas dan hanya memiliki barang-barang berharga berupa emas, kendaraan, alat-alat elektronik dan barang berharga lainnya.

Menurut Tim Pusat Bahasa dalam bukunya "Kamus Besar Bahasa Indonesia" (2008:403) mengatakan: "Gadai adalah meminjam uang di batas waktu tertentu dengan menyerahkan barang sebagai tanggungan, jika setelah sampai pada waktunya tidak ditebus, barang itu menjadi hak pemberi pinjaman. Barang yang diserahkan sebagai tanggungan utang, atau biasa disebut sebagai kredit jangka pendek dengan jaminan yang berlaku tiga bulan dan setiap kali dapat diperpanjang apabila tidak dihentikan oleh salah satu pihak yang bersangkutan".

Lembaga pegadaian konvensional yang sudah ada berhasil menumbuhkan citra baik di mata masyarakat Indonesia, dan juga munculnya perkembangan perbankan syariah yang mendapat respon positif dari masyarakat telah mendorong bank-bank syariah ini untuk membuka layanan gadai dengan sistem syariah. Hal ini juga didukung dengan dikeluarkannya peraturan perbankan oleh Bank Indonesia yaitu Surat Edaran (SE) Bank Indonesia No. 14/7/Dpbs tentang Produk Qardh Beragun Emas bagi Bank Syariah dan Unit Usaha
Syariah dan Fatwa oleh Dewan Syariah Nasional (DSN) MUI No. 26/DSNMUI/III/2002 tentang Rahn Emas yang memperbolehkannya gadai syariah.

Lahirnya bisnis gadai syariah yang dibuka oleh para lembaga perbankan syariah telah memunculkan persaingan antara bankbank syariah guna menjadi pemenang dalam merebut pasar gadai nasional yang dapat terkonversi menjadi sebuah keuntungan yang besar bagi perusahaan. Persaingan yang semakin ketat antara bank-bank syariah terkadang membuat para lembaga perbankan syariah tersebut mengambil jalan pintas untuk memperoleh keuntungan besar sehingga dalam menjalankan proses gadai telah melanggar aturan fatwa atau hukum gadai syariah yang ada.

Dalam perjanjian gadai konvensional yang ada saat ini adalah adanya bunga gadai, yang mana pembayarannya harus tepat dilakukan setiap 15 hari sekali. Jika pembayaran yang dilakukan mengalami keterlambatan, maka bunga gadai akan bertambah menjadi 2 kali lipat dari kewajibannya. Bukan hanya bunga riba yang terdapat dalam proses gadai tersebut, tetapi ketidakjelasan (gharar), dan qimar juga ikut serta menghiasi aktivitas bisnis tersebut. Sehingga masalah akan muncul ketika masyarakat terjebak dengan mulai membengkaknya biaya bunga yang harus dibayar serta ketidaksanggupan untuk melakukan pembayaran bunga tersebut dan sangat jelas akan mengakibatkan kecenderungan merugikan salah satu pihak.

Pada sistem gadai syariah menggunakan sistem akad. Menurut H. Ahmad Wardi Muslich (2010:112), “Akad adalah ikatan yang terjadi antara dua pihak, yang satu menyatakan 


\section{TRANSPARANSI}

Jurnal Ilmiah Ilmu Administrasi

ISSN 2085-1162

ijab dan yang kedua menyatakan qabul, yang kemudian menimbulkan akibat-akibat hukum, yaitu timbulnya hak dan kewajiban antara dua pihak tersebut." Akad dalam Islam sangatlah bersifat sakral. Dalam proses bisnis gadai syariah ini ada dua akad yang digunakan, yaitu akad Rahn (gadai) dan akad Ijarah (sewamenyewa).

Dalam pengamatan awal penulis pada lembaga perbankan syariah yaitu di Bank Syariah Mandiri secara sekilas proses gadai konvensional dan gadai syariah terlihat sama yaitu baik pegadaian konvensional dan pegadaian syariah diwajibkan membayar dana pinjamannya serta kewajiban lain yang telah ditentukan oleh pegadaian konvensional maupun pegadaian syariah. Apabila sampai dengan jatuh tempo perjanjian, pemberi gadai tidak melunasi pinjamannya dan tidak juga melakukan perpanjangan, maka pihak pegadaian konvensional maupun pegadaian syariah akan melakukan proses pelelangan. Apabila hasil lelang tidak cukup untuk melunasi pinjaman maka pemberi gadai wajib membayar sisa kewajiban pada pihak pegadaian dan sebaliknya bila ada kelebihan hasil dari pelelangan barang jaminan maka pemberi gadai berhak menerima kelebihannya.

Oleh karena itu, dari uraian di atas, penulis ingin melakukan penelitian untuk mengetahui apakah prosedur gadai syariah yang dilakukan Bank Syariah Mandiri dalam produk BSM Gadai (Rahn) Emas sudah sesuai dengan peraturan perbankan syariah yang ada yaitu yang dikeluarkan BI dan Fatwa oleh Dewan Syariah Nasional (DSN) MUI. Penelitian tersebut tertuang dalam penelitian skripsi yang berjudul "Analisis Prosedur BSM Gadai (Rahn) Emas Perspektif SE Bank Indonesia No.14/7/Dpbs dan Fatwa DSN MUI No. 26/DSN-MUI/III/2002"

Berdasarkan latar belakang di atas, maka dirumuskan, Apakah prosedur BSM Gadai Emas di Bank Syariah Mandiri sudah sesuai dengan SE Bank Indonesia No.14/7/Dpbs dan Fatwa DSN MUI No. 26/DSN-MUI/III/2002?
Volume VIII, Nomor 02, September 2016

Adapun tujuan penelitian ini adalah untuk menerangkan kesesuaian prosedur BSM Gadai Emas dengan SE Bank Indonesia No.14/7/Dpbs dan Fatwa DSN MUI No. 26/DSN-MUI/III/2002.

\section{METODE PENELITIAN}

Metode yang digunakan dalam penelitian ini adalah studi kasus (case study) dengan pendekatan kualitatif. Penelitian ini bertujuan untuk mengetahui tentang suatu hal secara mendalam. Sebagaimana pendapat Lincoln dan Guba (Deddy Mulyana, 2004:201), "Penggunaan studi kasus sebagai suatu metode penelitian kualitatif memiliki beberapa keuntungan antara lain: (1). Studi kasus dapat menyajikan pandangan dari subjek yang diteliti; (2). Studi kasus menyajikan uraian yang menyeluruh yang mirip dengan apa yang dialami pembaca kehidupan sehari-hari; (3). Studi kasus merupakan sarana efektif untuk menunjukkan hubungan antara penulis dan responden; (4). Studi kasus dapat memberikan uraian yang mendalam yang diperlukan bagi penilaian atau transferbalitas."

Maka dari itu, dalam penelitian ini penulis akan menggunakan metode studi kasus untuk mengungkapkan secara mendalam dan menyeluruh tentang analisis prosedur BSM Gadai Emas terhadap perspektif regulator yang mengaturnya yaitu SE Bank Indonesia No.14/7/Dpbs dan Fatwa DSN MUI No. 26/DSN-MUI/III/2002.

Menurut Sugiyono (2009:221), "Penelitian kualitatif tidak menggunakan istilah populasi, tetapi dinamakan social situation atau situasi sosial yang terdiri dari tiga elemen yaitu: tempat, pelaku dan aktivitas yang berinteraksi secara sinergis." Situasi sosial dalam penelitian ini adalah pihak PT Bank Syariah Mandiri.

Sampel dalam penelitin kualitatif bukan dinamakan responden, tetapi sebagai narasumber atau partisipan/informan. Informan dalam penelitian ini adalah pihak bank yang terdiri dari pegawai Pawning Group, pegawai 
Police and Procedure Group dan beberapa nasabah gadai Bank Syariah Mandiri.

Untuk memperoleh data yang diperlukan dalam penelitian ini, teknik pengumpulan data yang akan penulis gunakan adalah sebagai berikut:Wawancara Mendalam (Indepth Interview), Kuesioner, Observasi, dan Penelitian Kepustakaan (Library Research)

\section{TINJAUN PUSTAKA}

\section{Pengertian Prosedur}

"Prosedur (Procedure) adalah uruturutan seri tugas yang saling berkaitan dan dibentuk guna menjamin pelaksanaan kerja yang seragam." (M.Nafarin, 2009:9).

Selanjutnya menurut Mulyadi dalam bukunya yang berjudul "Sistem Akuntansi" (2001:5) mengatakan: Prosedur adalah suatu urutan kegiatan krelikal, biasanya melibatkan beberapa orang dalam satu departemen atau lebih, yang dibuat untuk menjamin penanganan secara seragam transaksi perusahaan yang terjadi berulang-ulang.

Menurut Tim Pusat Bahasa (2008:1106), "Prosedur adalah tahap kegiatan untuk menyelesaikan suatu aktivitas, metode langkah demi langkah secara pasti dalam memecahkan suatu masalah."

Kemudian menurut Azhar Susanto (2004:264), "Prosedur adalah rangkaian aktivitas atau kegiatan yang dilakukan secara berulang-ulang dengan cara yang sama."

Berdasarkan pendapat para ahli tersebut di atas, maka penulis mengambil kesimpulan bahwa prosedur adalah urutan dari serangkaian aktivitas/kegiatan yang dilakukan dalam sebuah organisasi/perusahaan guna menyelesaikan suatu pekerjaan secara seragam yang terjadi berulang-ulang.

\section{Karakteristik Prosedur}

Berikut ini adalah beberapa
karakteristik prosedur, menurut Mulyadi
(2001:8), Karakteristik prosedur adalah sebagai
berikut: (1). Prosedur menunjang tercapainya
tujuan organisasi; (2). Prosedur mampu
menciptakan adanya pengawasan yang baik dan

menggunakan biaya yang seminimal mungkin; (3). Prosedur menunjukkan urutan-urutan yang logis dan sederhana; (4) Prosedur menunjukkan adanya penetapan keputusan dan tanggung jawab.

\section{Manfaat Prosedur}

Suatu prosedur juga sangat memberikan manfaat yang besar bagi organisasi/perusahaan. Menurut Mulyadi (2001:15), Manfaat prosedur adalah sebagai berikut: (a). Lebih memudahkan dalam menentukan langkah-langkah kegiatan dimasa yang akan dating; (b). Mengubah pekerjaan yang berulang-ulang menjadi rutin dan terbatas, sehingga menyederhanakan pelaksanaan dan untuk selanjutnya mengerjakan yang seperlunya saja; (c). Adanya suatu petunjuk atau program kerja yang jelas dan harus dipatuhi oleh seluruh pelaksana; (d). Membantu dalam usaha meningkatkan produktifitas kerja yang efektif dan efisien; (e). Mencegah terjadinya penyimpangan dan memudahkan dalam pengawasan, bila terjadi penyimpangan akan dapat segera diadakan perbaikan-perbaikan sepanjang dalam tugas dan fungsinya masing-masing.

\section{Gadai (Rahn)}

"Gadai (rahn) adalah menjadikan suatu barang sebagai jaminan atas utang dengan ketentuan bahwa apabila terjadi kesulitan dalam pembayarannya maka utang tersebut bisa dibayar dari hasil penjualan barang yang dijadikan jaminan itu." (H. Ahmad Wardi Muslich, 2010:288).

Menurut Ahmad Azhar Basyir dalam bukunya berjudul "Hukum Islam tentang Riba, Utang-Piutang Gadai” (1983:50), Gadai (rahn) adalah perjanjian menahan sesuatu barang sebagai tanggungan utang, atau menjadikan sesuatu benda bernilai menurut pandangan syara' sebagai tanggungan marhun bih, sehingga dengan adanya tanggungan utang itu seluruh atau sebagian utang dapat diterima."

Selain itu, menurut Muhammad Syafi'i Antonio (2001:128) "Gadai syariah (rahn) adalah menahan salah satu harta milik nasabah (rahin) sebagai barang jaminan (marhun) atas 
Jurnal Ilmiah Ilmu Administrasi

ISSN 2085-1162

utang/pinjaman (marhun bih) yang diterimanya."

Gadai (rahn) juga dikemukakan oleh Muhammad (2007:64), "Menahan salah satu harta milik seseorang (peminjam) sebagai jaminan atas pinjaman yang diterimanya. Barang yang ditahan tersebut memiliki nilai ekonomis, dengan demikian pihak yang menahan memperoleh jaminan untuk dapat mengambil kembali seluruh atau sebagian piutangnya.

"Gadai dalam bahas Arab disebut Rahn. Secara bahasa, rahn berarti tetap dan lestari, seperti juga dinamai al-habsu, artinya penahanan", (Muhammad Firdaus NH dkk, 2005:90).

Kemudian Zainuddin Ali dalam bukunya yang berjudul "Hukum Gadai Syariah" (2008:3) berpendapat, "Gadai (rahn) adalah menahan barang yang bersifat materi milik si peminjam (rahin) sebagai jaminan atas pinjaman yang diterimanya, dan barang yang diterima tersebut bernilai ekonomis, sehingga pihak yang menahan (murtahin) memperoleh jaminan untuk mengambil kembali seluruh atau sebagian utangnya dari barang gadai dimaksud, bila pihak yang menggadaikan tidak dapat membayar utang pada waktu yang telah ditentukan."

Dari uraian pendapat para ahli di atas, penulis menarik sebuah kesimpulan mengenai pengertian gadai ( $\mathrm{rahn}$ ) adalah menahan suatu barang yang dimiliki oleh peminjam (rahin) yang bernilai ekonomis, barang tersebut dijadikan sebagai jaminan atas utang yang diterimanya, barang tersebut juga dapat dijadikan sebagai pembayar utang jika peminjam tidak dapat membayar utangnya pada waktu yang telah ditentukan.

\section{Landasan Hukum Gadai (Rahn) Syariah Berdasarkan Al-Quran}

Dalam Al-Quran yang digunakan sebagai dasar dalam membangun konsep gadai adalah sebagai berikut: "Jika kamu dalam perjalanan (dan bermuamalah tidak secara tunai) sedang kamu tidak memperoleh seorang penulis, maka hendaklah ada barang tanggungan yang dipegang (oleh yang berpiutang). Akan tetapi, jika sebagian kamu mempercayai sebagian yang lain, maka hendaklah yang dipercayai itu menunaikan amanatnya (utangnya) dan hendaklah ia bertakwa kepada Allah SWT, dan janganlah kamu (para saksi) menyembunyikan persaksian. Dan barangsiapa yang menyembunyikannya, maka sesungguhnya ia adalah orang yang berdosa hatinya, dan Allah Maha Mengetahui apa yang kamu kerjakan." (QS. Al-Baqarah: 283).

\section{Berdasarkan Hadist Nabi Muhammad SAW}

Hadist dari kitab Shahih Muslim (1993:51), 'Aisyah ra.yang diriwayatkan oleh Imam Muslim, yang berbunyi: "telah meriwayatkan kepada kami Ishaq bin Ibrahim Al-Hanzhali dan Ali bin Khasyram berkata: keduanya mengabarkan kepada kami Isa bin Yunus bin 'Amasy dari Ibrahim dari Aswad dari 'Aisyah berkata: bahwasanya Rasulullah SAW membeli makanan dari seorang Yahudi dengan menggadaikan baju besinya." (HR. Muslim).

Kemudian dari kitab Sunan Ibnu Majah (1995:18), hadist dari Anas bin Malik ra. yang diriwayatkan oleh Ibnu Majah yang berbunyi: "Telah meriwayatkan kepada kami Nashr bin Ali Al-Jahdhami, ayahku telah meriwayatkan kepadaku, meriwayatkan kepada kami Hisyam bin Qatadah dari Anas berkata: Sungguh Rasulullah SAW menggadaikan baju besinya kepada seorang Yahudi di Madinah dan menukarnya dengan gandum untuk keluarganya." (HR. Ibnu Majah).

Hadist dari Abu Hurairah yang diriwayatkan oleh Imam Al-Bukhari yang terdapat dalam kitab Shahih Al-Bukhari (1983:116) yang berbunyi: "Telah diriwayatkan kepada kami Muhammad bin Muqatil, mengabarkan kepada kami Abdullah bin Mubarak, mengabarkan kepada kami Zakariyya dari Sya'bi dari Abu Hurairah, dari Nabi Muhammad SAW, bahwasanya beliau besabda: Kendaraan dapat digunakan dan hewan ternak 
dapat pula diambil manfaatnya apabila digadaikan. Penggadaian wajib memberikan nafkah dan penerima gadai boleh mendapatkan manfaatnya. (HR. Al-Bukhari).

\section{Berdasarkan Ijma’ Ulama}

Para ulama telah menyepakati bahwa gadai ini diperbolehkan.Hal ini sejalan dengan H. Zainuddin Ali (Wahbah Zuhaily, 2002:4210) mengemukakan,“Jumhur ulama menyepakati kebolehan status hukum gadai.Hal dimaksud, berdasarkan pada kisah Nabi Muhammad SAW yang menggadaikan baju besinya untuk mendapatkan makanan dari seorang Yahudi. Para ulama juga mengambil indikasi dari contoh Nabi Muhammad SAW tersebut, ketika beliau beralih dari yang biasanya bertransaksi kepada para sahabat yang kaya kepada seorang Yahudi, bahwa hal itu tidak lebih sebagai sikap Nabi Muhammad SAW yang tidak mau memberatkan para sahabat yang biasanya enggan mengambil ganti ataupun harga yang diberikan oleh Nabi Muhammad SAW kepada mereka."

\section{Fatwa Dewan Syariah Nasional MUI}

Fatwa DSN MUI No.25/DSN-MUI/III2002

Fatwa yang dikeluarkan pada tanggal 26 Juni 2002 ini menyatakan, bahwa jaminan utang dalam bentuk rahn diperbolehkan dengan ketentuan sebagai berikut:

\section{Ketentuan Umum}

(1). Penerima barang (murtahin) mempunyai hak untuk menahan barang (marhun) sampai semua utang pihak yang menyerahkan barang (rahin) dilunasi; (2). Barang (marhun) dan manfaatnya tetap menjadi milik pihak yang menyerahkan barang (rahin). Pada prinsipnya, barang (marhun) tidak boleh dimanfaatkan oleh penerima barang (murtahin) kecuali seizin pemilik barang (rahin), dengan tidak mengurangi nilai barang (marhun) dan pemanfaatannya itu sekedar pengganti biaya pemeliharaan dan perawatannya; (3). Pemeliharaan dan penyimpanan. Barang (marhun) pada dasarnya menjadi kewajiban pemilik barang (rahin), namun dapat dilakukan juga oleh penerima barang (murtahin), sedangkan biaya dan pemeliharaan penyimpanan tetap menjadi kewajiban pemilik barang (rahin); (4). Besar biaya administrasi dan peyimpanan barang (marhun) tidak boleh ditentukan berdasarkan jumlah pinjaman; (5). Penjualan Barang (Marhun); (a). Apabila jatuh tempo, penerima barang (murtahin) harus memperingatkan pemilik barang (rahin) untuk segera melunasi utangnya; (b). Apabila pemilik barang (rahin) tetap tidak dapat melunasi utangnya, maka barang (marhun) dijual paksa/dieksekusi; (c). Hasil penjualan barang (marhun) digunakan untuk melunasi utang, biaya pemeliharaan dan penyimpanan yang belum dibayar serta biaya penjualan/lelang; (d). Kelebihan hasil penjualan menjadi milik dari pemilik barang (rahin) dan kekurangannya menjadi kewajiban pemilik barang (rahin).

\section{Ketentuan Tertutup}

(1). Jika salah satu pihak tidak menunaikan kewajibannya atau jika terjadi perselisihan diantara kedua belah pihak, maka penyelesaiannya dilakukan melalui Badan Arbitrase Syariah setelah tidak tercapai kesepakatan melalui musyawarah; (2). Fatwa ini berlaku sejak tanggal ditetapkannya dengan ketentuan jika dikemudian hari ternyata terdapat kekeliruan, akan diubah dan disempurnakan sebagaimana mestinya.

\section{Fatwa DSN MUI No.26/DSN-MUI/III2002}

Fatwa tentang Rahn Emas yang dikeluarkan pada tanggal 28 Maret 2002 ini menyatakan, bahwa keputusan DSN adalah sebagai berikut: (1). Rahn Emas diperbolehkan berdasarkan prinsip Rahn. (lihat Fatwa DSN MUI No.25/DSN-MUI/III2002); (2). Ongkos dan biaya penyimpanan barang gadai (marhun) ditanggung oleh penggadai (rahin); (3). Ongkos sebagaimana dimaksud ayat (2) besarnya didasarkan pada pengeluaran yang diperlukan sebenarnya; (4). Biaya penyimpanan barang gadai (marhun) dilakukan berdasarkan akad Ijarah.

Surat Edaran (SE) Bank Indonesia No. 14/7/Dpbs tanggal 29 Februari 2012 Umum 
(1). Qardh adalah suatu akad penyaluran dana oleh Bank Syariah atau UUS kepada nasabah sebagai utang piutang dengan ketentuan bahwa nasabah wajib mengembalikan dana tersebut kepada Bank Syariah atau UUS pada waktu yang telah disepakati; (2). Akad Qardh terdiri atas 2 (dua) macam; (a). Akad Qardh yang berdiri sendiri, dengan karakteristik sebagai berikut: Pembiayaan digunakan untuk tujuan sosial dan bukan untuk mendapatkan keuntungan; (b). Sumber dana dapat berasal dari bagian modal, keuntungan yang disishkan, dan/atau zakat, infak, sedekah dan tidak boleh menggunakan dana pihak ketiga; (c). Jumlah pinjaman wajib dikembalikan pada waktu yang telah disepakati; (d). Tidak boleh dipersyaratkan adanya imbalan dalam bentuk apapun; (e). Nasabah dapat memberikan tambahan (sumbangan) dengan sukarela selama tidak diperjanjikan dalam akad, dan; (f). Nasabah dapat dikenakan biaya administrasi; (g). Akad qardh yang dilakukan bersamaan dengan transaksi lain yang menggunakan akad-akad mu'awadhah (pertukaran dan dapat bersifat komersial) dalam produk yang bertujuan untuk mendapatkan keuntungan, dapat dilakukan antara lain dalam produk rahn emas, pembiayaan pengurusan haji, pengalihan utang, syariah charge card, syariah card, dan anjak piutang syariah.

(2). Qardh beragun emas adalah salah satu produk yang menggunakan akad qardh dengan agunan berupa emas yang diikat dengan akad rahn, dimana emas yang diagunkan disimpan dan dipelihara oleh Bank Syariah atau UUS selama jangka waktu tertentu dengan membayar biaya penyimpanan dan pemeliharaan atas emas sebagai objek rahn yang diikat dengan akad ijarah.

\section{Karakteristik Produk Qardh Beragun Emas}

Tujuan penggunaan adalah untuk membiayai keperluan dana jangka pendek atau tambahan modal kerja jangka pendek untuk golongan nasabah Usaha Mikro dan Kecil sebagaimana dimaksud dalam Undang-Undang
Nomor 20 Tahun 2008 tentang Usaha Mikro, Kecil, dan Menengah, serta tidak dimaksudkan untuk tujuan investasi; (1). Akad yang digunakan adalah sebagai berikut: (a). Akad qardh, untuk pengikatan pinjaman dana yang disediakan Bank Syariah atau UUS kepada nasabah; (b). Akad rahn, untuk pengikatan emas sebagai agunan atas pinjaman dana, dan; (c). Akad ijarah, untuk pengikatan pemanfaatan jasa penyimpanan dan pemeliharaan emas sebagai agunan pinjaman dana. (2). Biaya yang dapat dikenakan oleh Bank Syariah atau UUS kepada nasabah antara lain biaya administrasi, biaya asuransi, dan biaya penyimpanan dan pemeliharaan; (3). Penetapan besarnya biaya penyimpanan dan pemeliharaan agunan emas didasarkan pada berat agunan emas dan tidak dikaitkan dengan jumlah pinjaman yang diterima nasabah; (4). Sumber dana dapat berasal dari bagian modal, keuntungan yang disisihkan, dan/atau dana pihak ketiga; (5). Pendapatan dari penyimpanan dan pemeliharaan emas yang berasal dari produk Qardh Beragun Emas yang sumber dananya berasal dari dana pihak ketiga harus dibagikan kepada nasabah penyimpan dana; (6). Pemberian Qardh Beragun Emas wajib didukung kebijakan dan prosedur (Standard Operating Procedure/SOP) tertulis secara memadai, termasuk penerapan manajemen risiko; (8). Bank Syariah atau UUS wajib menjelaskan secara lisan atau tertulis (transparan) kepada nasabah antara lain: (a). Karakteristik produk antara lain fitur, risiko, manfaat, biaya, persyaratan, dan penyelesaian apabila terdapat sengketa; (b). Hak dan kewajiban nasabah termasuk apabila terjadi eksekusi agunan emas.

Prinsip Kehati-hatian dalam Penerapan Produk Qardh Beragun Emas (1). Tujuan penggunaan dana oleh nasabah wajib dicantumkan secara jelas pada formulir aplikasi produk; (2). Emas yang akan diserahkan sebagai agunan Qardh Beragun Emas harus sudah dimiliki oleh nasabah pada saat permohonan pembiayaan diajukan; (3). Jumlah portofolio Qardh Beragun Emas pada setiap 
akhir bulan paling banyak: (a). Untuk Bank Syariah, jumlah yang lebih kecil antara sebesar $20 \%$ (dua puluh persen) dari jumlah seluruh pembiayaan yang diberikan atau sebesar $150 \%$ (seratus lima puluh persen) dari modal bank sebagaimana dimaksud dalam ketentuan Bank Indonesia yang mengatur mengenai Kewajiban Penyediaan Modal Minimum (KPMM), (b). Untuk UUS, sebesar 20\% (dua puluh persen) dari jumlah seluruh pembiayaan yang diberikan. (2). Pembiayaan Qardh Beragun Emas dapat diberikan paling banyak sebesar Rp250.000.000,00 (dua ratus lima puluh juta rupiah) untuk setiap nasabah, dengan jangka waktu pembiayaan paling lama 4 (empat) bulan dan dapat diperpanjang paling banyak 2 (dua) kali; (3). Khusus untuk nasabah Usaha Mikro dan Kecil, dapat diberikan pembiayaan Qardh Beragun Emas paling banyak sebesar Rp50.000.000,00 (lima puluh juta rupiah), dengan jangka waktu pembiayaan paling lama 1 (satu) tahun dengan angsuran setiap bulan dan tidak dapat diperpanjang; (4). Financing To Value (FTV) yang merupakan perbandingan antara jumlah pinjaman yang diterima oleh nasabah dengan nilai emas yang diagunkan oleh nasabah kepada Bank Syariah atau UUS, paling banyak adalah sebesar $80 \%$ (delapan puluh persen) dari rata-rata harga jual emas 100 (seratus) gram dan harga beli kembali (buyback) emas PT. ANTAM (Persero) Tbk.

\section{Rukun Gadai (Rahn)}

Dalam menjalankan gadai (rahn) syariah, lembaga harus memenuhi rukun gadai (rahn) syariah. Menurut Heri Sudarsono (2003:160), rukun gadai (rahn) tersebut adalah sebagai berikut: (1). Ar-Rahn (yang menggadaikan) Orang yang telah dewasa, berakal sehat, dapat dipercaya, dan memiliki barang bernilai untuk digadaikan; (2). AlMurtahin (yang menerima gadai) Orang, bank, atau lembaga yang dipercaya oleh rahin untuk mendapatkan modal dengan memberikan jaminan barang (gadai); (3). Al-Marhun (barang yang digadaikan) Barang yang digunakan rahin untuk dijadikan jaminan dalam mendapatkan uang/modal; (4). Al-Marhun Bih (utang) Sejumlah dana yang diberikan murtahin kepada rahin atas dasar besarnya taksiran marhun; (5). Sighat, Ijab dan Qabul Kesepakatan antara rahin dan murtahin dalam melakukan transaksi gadai.

\section{Syarat-Syarat Gadai (Rahn)}

Selain rukun yang harus terpenuhi dalam transaksi gadai (rahn), maka dipersyaratkan juga dengan syarat-syarat gadai (rahn) yang menurut H. Zainuddin Ali (2008: 21-25), memiliki beberapa syarat diantaranya: (1). Shigat Syarat shigat tidak boleh terikat dengan syarat tetentu dan waktu yang akan datang. Kecuali jika syarat itu mndukung kelancaran akad maka diperbolehkan; (2). Pihak-Pihak yang Berakad Cakap Menurut Hukum Pihak-pihak yang berakad harus cakap menurut hukum mempunyai pengertian bahwa pihak rahin dan marhun cakap elakukan perbuatan hukum, yang ditandai dengan aqil baligh, berakal sehat, dan mampu melakukan akad; (3). Utang (Marhun Bih)bUtang (marhun bih) mempunyai pengertian bahwa utang adalah kewajiban bagi pihak berutang unuk membayar kepada pihak yang memberi piutang; (4). Marhun Marhun adalah harta yang dipegang oleh murtahin (penerima gadai) atau wakilnya, sebagai jaminan utang.

\section{Hak dan Kewajiban Gadai (Rahn) Syariah}

\section{Hak dan Kewajiban Murtahin} (Penerima Gadai). Menurut Buchari Alma (2009:34) adalah sebagai berikut: (1). Hak Penerima Gadai (Murtahin) terdiri dari: (a). Pemegang gadai berhak menjual barang gadai (marhun) apabila pemberi gadai (rahin) tidak dapat memenuhi kewajibannya pada saat jatuh tempo. Hasil penjualannya barang gadai (marhun) akan dapat digunakan untuk melunasi pinjaman (marhun bih) dan sisanya akan dikembalikan kepada pemberi gadai (rahin); (b). Pemegang gadai berhak mendapatkan pergantian biaya yang telah dikeluarkan untuk menjaga keselamatan barang gadai (marhun); (c). Selama pinjaman belum dilunasi, pemegang gadai berhak menahan barang gadai yang diserahkan oleh pemberi gadai (rahin). (2). Kewajiban Penerima Gadai (Murtahin) terdiri dari: (a). Penerima gadai (murtahin) 
bertanggung jawab atas hilang atau merosotnya barang gadai (marhun), apabila hal itu disebabkan oleh kelalaiannya; (b). Penerima gadai (murtahin) tidak boleh menggunakan barang gadai (marhun) untuk kepentingan sendiri (c). Penerima gadai (murtahin) wajib memberitahukan kepada pemberi gadai (rahin) sebelum diadakan pelelangan barang gadai (marhun).

\section{Hak dan Kewajiban Pemberi Gadai (Rahin)}

Menurut Zainuddin Ali (2008:41) adalah sebagai berikut: (1). Hak Pemberi Gadai (Rahin) terdiri dari: (a). Pemberi gadai (rahin) behak mendapatkan pengembalian harta benda yang digadaikan sesudah ia melunasi pinjaman utangnya (marhun bih); (b). Pemberi gadai (rahin) berhak menuntut ganti rugi atau kerusakan dan atau hilangnya harta benda yang digadaikan, bila hal itu disebabkan oleh kelalaian penerima gadai (murtahin); (c). Pemberi gadai (rahin) berhak menerima sisa hasil penjualan barang gadai (marhun) sesudah dikurangi biaya pinjaman dan biaya-biaya lainnya; (d). Pemberi gadai (rahin) berhak meminta kembali barang gadai (marhun) apabila penerima gadai (murtahin) diketahui menyalahgunakan barang gadai (marhun) tersebut. (2). Kewajiban Pemberi Gadai (Rahin) terdiri dari: (a). Pemberi gadai (rahin) berkewajiban melunasi pinjaman/utang (marhun bih) yang telah diterimanya dalam tenggang waktu yang telah ditentukan, termasuk biaya-biaya yang ditentukan oleh penerima gadai (murtahin); (b). Pemberi gadai (rahin) berkewajiban merelakan penjualan barang gadai (marhun), bila dalam jangka waktu yang telah ditentukan akan tetapi pemberi gadai (rahin) tidak dapat melunasi utangnya (marhun bih).

\section{Mekanisme Pemberian Pinjaman, Sistem Cicilan dan Perpanjangan Utang}

Mekanisme dalam gadai (rahn) syariah sangatlah panjang. Berikut adalah mekanisme secara garis besar dalam gadai ( $r a h n)$ menurut
Zainuddin Ali (2008:45-51), antara lain: (1). Mekanisme Pemberian Pinjaman; Mekanisme penyaluran pinjaman pada pelaksanaan sistem gadai syariah mempunyai prinsip bahwa nasabah hanya dibebani oleh biaya administrasi dan jasa penyimpanan harta benda jaminan.Selain itu, untuk mendapatkan pinjaman, barang yang dimiliki harus terlebih dahulu ditaksir oleh petugas penaksir.Tujuannya adalah menghitung besarnya jumlah pinjaman yang dapat dipinjamkan oleh tempat melakukan permohonan gadai. Berdasarkan jumlah pinjaman itu, akan ditentukan golongan pinjaman dan berapa tingkat biaya administrasi yang harus dipegang. Setelah perhitungan itu selesai maka peminjam dapat menerima pembayaran uang pinjaman tanpa potongan apapun, kecuali premi asuransi (tetapi tergantung tempat permohonan gadai).

Demikian pula, apabila ingin melunasi pinjaman.Pelunasan tidak harus menunggu jatuh tempo.Artinya, bila jangka waktu pinjaman itu 4 (empat) bulan maka nasabah dapat melunasi walaupun periode pinjaman belum berakhir.Mekanisme pelaksanaan gadai syariah merupakan implementasi dari beberapa konsep yang telah ditetapkan oleh beberapa ulama tentang gadai (rahn). (1). Sitem Cicilan dan Perpanjangan Utang (Marhun Bih) pada dasarnya orang yang menggadaikan (rahin) hartanya di tempat gadai untuk mendapatkan pinjaman uang dapat melunasi pinjamannya apan saja, tanpa harus menunggu jatuh tempo. Namun, pemberi gadai (rahin) dapat memberi pilihan cara pelunasan sekaligus ataupun mencicil utangnya. Selain itu, perlu diungkapkan bahwa ketentuan jumlah pinjaman didasari oleh kualitan dan kuantitas barang yang digadaikan. Harta benda yang akan digadaikan ditaksir berdasarkan pertimbangan jenis harta, nilai harta dan lain-lain. (2). Proses Pelelangan Barang Gadai (Marhun) Pihak pegadaian akan melakukan pelelangan jika pemberi gadai (rahin) tidak dapat melunasi sampai batas waktu yang telah ditentukan dalam akad. Pelelangan dilakukan oleh pihak 
penerima gadai (murtahin) setelah sebelumnya diberitahukan kepada pemberi gadai (rahin) paling lambat 5 (lima) hari sebelum tanggal penjualan. Pelelangan dimaksud mempunyai ketentuan sebagai berikut: (a). Ditetapkan harga emas oleh penerima gadai (murtahin) pada saat pelelangan dengan margin $2 \%$ untuk pembeli; (b). Harga penawaran yang dilakukan oleh banyak orang tidak boleh dilakukan karena dapat merugikan bagi pemberi gadai (rahin). Karena itu, dilakukan pelelangan terbatas; (c). Hasil pelelangan akan digunakan untuk biaya penjualan $1 \%$ dari harga jual, biaya pinjaman 4 (empat) bulan dan sisanya dikembalikan kepada pemberi gadai (rahin); (d). Sisa kelebihan yang tidak diambil selama setahun, akan diserahkan oleh pihak penerima gadai (murtahin) kepada baitul mal.

Berdasarkan teori-teori di atas, penulis mengambil sebuah kesimpulan pengertian prosedur adalah urutan dari serangkaian aktivitas/kegiatan yang direncanakan dan dilakukan dalam sebuah organisasi/perusahaan guna menyelesaikan suatu pekerjaan secara seragam yang terjadi berulang-ulang.

Sedangkan kesimpulan pengertian gadai (rahn) adalah menahan suatu barang yang dimiliki oleh peminjam (rahin) yang bernilai ekonomis, barang tersebut dijadikan sebagai jaminan atas utang yang diterimanya, barang tersebut juga dapat dijadikan pembayar utang jika peminjam tidak dapat membayar utangnya pada waktu yang telah ditentukan.

Berdasarkan kesimpulan pengertian di atas, maka penulis dapat menarik sebuah keterkaitan penelitian ini adalah serangkaian urutan aktivitas kegiatan yang dilakukan sebuah organisasi/perusahaan untuk memberikan pinjaman sejumlah dana, kemudian menahan suatu barang tertentu yang dimiliki dari seseorang yang barang tersebut bernilai ekonomis guna dijadikan jaminan atas dana pinjaman yang diterimanya.

Selain itu, keterkaitan tersebut akan kembali disesuaikan antara pelaksanaan prosedur gadai (rahn) syariah dengan semua ketentuan yang mengatur di dalamnya diantaranya peraturan Bank Indonesia yaitu melalui Surat Edaran (SE) Bank Indonesia No. 14/7/Dpbs tentang Produk Qardh Beragun
Emas bagi Bank Syariah dan Unit Usaha Syariah dan melalui Fatwa oleh Dewan Syariah Nasional (DSN) MUI No. 26/DSNMUI/III/2002 tentang Rahn Emas.

Hipotesis yang dapat diperoleh penulis adalah adanya ketidaksesuaian antara prosedur gadai (rahn) emas yang dilakukan oleh Bank Syariah Mandiri dengan ketentuan Bank Indonesia dan Fatwa Dewan Syariah Nasional (DSN) MUI. Hal ini dikarenakan penulis melihat secara umum bahwa gadai syariah belum bisa memperlihatkan perbedaan yang signifikan dengan gadai konvensional sebagaimana yang diatur oleh regulator.

\section{SIMPULAN DAN SARAN Simpulan}

Hasil penelitian mengenai "Analisis Prosedur BSM Gadai (Rahn) Emas Perspektif SE Bank Indonesia No.14/7/Dpbs tentang Produk Qardh Beragun Emas Bagi Bank Syariah dan Unit Usaha Syariah dan Fatwa DSN MUI No. 26/DSN-MUI/III/2002 tentang Rahn Emas" yang telah penulis lakukan melalui wawancara, kuesioner, observasi dan penelitian kepustakaan menunjukkan bahwa: (1). Dalam setiap penawaran produk BSM Gadai (Rahn) Emas yang dilakukan pegawai gadai kepada nasabah Bank Syari'ah Mandiri, dilakukan secara terperinci dengan menjelaskan mulai dari akad yang dipergunakan, besarnya nilai pembiayaan, serta proses pelunasan. Hal ini sesuai dengan Karakteristik Produk Qardh Beragun Emas yang terdapat pada SE BI No.14/7/DPbS; (2). Jangka waktu gadai yang diberlakukan oleh Bank Syariah Mandiri yaitu selama maksimal 4 bulan (120 hari) per periode dan dapat diperpanjang maksimal 2 kali perpanjangan. Hal ini sesuai dengan Prinsip Kehati-Hatian Dalam Penerapan Produk Qardh Beragun Emas yang terdapat pada SE BI No.14/7/DPbS; (3). Biaya pemeliharaan atau penyimpanan, biaya asuransi, biaya materai dan biaya administrasi menjadi tanggung jawab nasabah yang akan dibayarkan kepada bank. Hal ini sesuai Karakteristik Produk Qardh Beragun Emas yang terdapat pada SE BI No.14/7/DPbS dan putusan Fatwa DSN MUI No. 26/DSN-MUI/III/2002 pada ketetapan 
Ongkos dan biaya penyimpanan barang (marhun) ditanggung oleh penggadai (rahin); (4). Akad-akad yang menjadi dasar pelaksanaan gadai syariah ini diantaranya: (a). Akad qardh dalam rangka pemberian sejumlah dana pinjaman yang kesepakatannya akan dikembalikan sesuai dengan jumlah pinjamannya dalam jangka waktu tertentu. Hal ini seuai dengan Karakteristik Produk Qardh Beragun Emas yang terdapat pada SE BI No.14/7/DPbS; (b). Akad rahn dalam rangka pengikatan barang berharga berupa logam mulia atau perhiasan sebagai barang jaminan atau agunan yang akan ditahan oleh pihak bank. Hal ini sesuai dengan Karakteristik Produk Qardh Beragun Emas yang terdapat pada SE BI No.14/7/DPbS; (c). Akad ijarah dalam rangka sewa menyewa atas dasar biaya jasa penyimpana dan pemeliharaan atas barang jaminan atau agunan yang ditahan oleh pihak bank tersebut. Besarnya biaya pemeliharaan ini diperhitungkan berdasarkan nilai taksiran dari barang jaminan/agunan tersebut. Hal ini sesuai dengan Karakteristik Produk Qardh Beragun Emas yang terdapat pada SE BI No.14/7/DPbS dan putusan Fatwa DSN MUI No. 26/DSNMUI/III/2002 pada ketetapan Biaya penyimpanan barang (marhun) dilakukan berdasarkan akad Ijarah; (d). Dasar perhitungan biaya pemeliharaan atau penyimpanan atas barang jaminan nasabah gadai yang dikenakan oleh Bank syariah Mandiri, tidak dikenakan berdasarkan jumlah pinjaman, akan tetapi berdasarkan nilai taksiran barang jaminan pinjaman/pembiayaan nasabah. Hal ini sesuai dengan Karakteristik Produk Qardh Beragun Emas yang terdapat pada SE BI No.14/7/DPbS dan putusan Fatwa DSN MUI No. 25/DSN-MUI/III/2002 pada ketetapan Besar biaya pemeliharaan dan penyimpanan Marhun tidak boleh ditentukan berdasarkan jumlah pinjaman; (e). Ketika sudah jatuh tempo, pihak Bank Syariah Mandiri akan memberikan peringatan berupa surat peringatan kepada nasabah-nasabah yang belum melakukan pelunasan atau perpanjangan atas gadai yang dilakukan sebelumnya. Tanggapan atas surat peringatan tersebut akan ditunggu selama 3 hari sambil mempersiapkan proses pelelangan jika nasabah tidak sanggup melakukan pelunasan dan tidak melakukan perpanjangan. Hal ini sesuai dengan putusan Fatwa DSN MUI No.25/DSN-MUI/III/2002 pada ketetapan Apabila jatuh tempo, Murtahin harus memperingatkan Rahin untuk segera melunasi utangnya.

\section{Saran}

Berdasarkan rangkuman kesimpulan dari analisis data di atas, maka penulis mencoba memberikan saran diantaranya mendorong pihak Bank Syariah Mandiri untuk dapat melakukan pengawasan agar penerapan prosedur produk BSM Gadai (rahn) Emas di semua konter layanan gadai Bank Syariah Mandiri yang ada di seluruh Indonesia benarbenar sesuai dengan peraturan yang terdapat dalam SE Bank Indonesia No.14/7/Dpbs tentang "Produk Qardh Beragun Emas Bagi Bank Syariah dan Unit Usaha Syariah" dan Fatwa DSN MUI No. 26/DSN-MUI/III/2002 tentang "Rahn Emas".Selain itu juga mempromosikan kembali produk BSM Gadai (rahn) Emas kepada masyarakat, guna memberikan pencerdasan akan ekonomi syariah agar masyarakat Indonesia yang mayoritas muslim ini tidak lagi merasa ragu ketika ingin mengambil sebuah produk syariah.

\section{DAFTAR PUSTAKA}

Al-Bukhari, Imam Abi Abdullah Muhammad bin Ismail Bin Ibrahim bin Mughirah bin Brdizbah. 1983. Shahih Al-Bukhari. (t.t): Dar Al-Fikr.

Ali, Faried. 2011. Teori dan Konsep Administrasi. Jakarta: Raja Grafindo Persada.

Ali, Zainuddin. 2008. Hukum Gadai Syariah. Jakarta: Sinar Grafika. 
Nidaul Izzah , Analisis Prosedur Bsm Gadai Emas Perspektif Se Bank Indonesia....

Amirullah dan Imam Hardjanto. 2005. Pengantar Bisnis. Yogyakarta: Graha Ilmu.

Basyir, Ahmad Azhar. 1983. Hukum Islam tentang Riba, Utang-Piutang Gadai. Bandung: Al-Maarif.

Boone, Louis E dan David L Kurtz. 2007. Contemporary Business, buku 1. Jakarta: Salemba 4.

Departemen Agama RI. 2005. Al-Qur'an dan Terjemahan. Jakarta: PT Syaamil Cipta Media.

Firdaus, Muhammad, N.H., et.al. 2005. Konsep Dasar Obligasi Syari'ah. Jakarta: Renaisan.

Firdaus, Muhammad. 2007. Mengatasi Masalah dengan Pegadaian Syariah. Jakarta: Reinesa.

Ibn Majah, Al-Hafidz Abi Abdillah Muhammad bin Yazid Al-Qazwiny. 1995. Sunan Ibn Majah. (t.t). Dar AlFikr.

Mulyadi. 2001. Sistem Akuntansi. Jakarta: Salemba 4.

Muslich, Ahmad Wardi. 2010. Fiqh Muamalat. Jakarta: Amzah.

Muslim, Imam Abi Husain Muslim Bin Hajjaj Al-Kusyairy An-Naisaburi. 1993. Shahih Muslim. (t.t). Dar Al-Fikr.

Nafarin, M. 2009. Penganggaran Perusahaan. Jakarta: Salemba 4.

Nawawi, Ismail. 2009. Perilaku Administrasi: Kajian Paradigma, Konsep, Teori dan Pengantar Praktik. Surabaya: ITS Press.

Siswandi. 2011. Metedologi Penelitian Bisnis. Jakarta: Salemba 4.
Antonio, Muhammad Syafii. 2001. Bank Syariah: Wacana Ulama dan Cendikiawan. Jakarta: Bank Indonesia dan Tazkia Institute.

Susanto, Azhar. 2004. Sistem Informasi Akuntansi Konsep dan Pengembangan Berbasis Komputer. Bandung: Lingga Jaya.

Tim Pusat Bahasa. 2008. Kamus Besar Bahasa Indonesia, Edisi 4. Jakarta: PT Gramedia Pustaka Utama.

Wibowo. 2008. Manajemen Kinerja. Jakarta: Raja Grafindo Persada.

Widiyono dan Pakkana Mukhaer. 2011. Pengantar Bisnis terhadap Dinamika Global. Jakarta: Mitra Kencana Media.

www.syariahmandiri.co.id, diakses pada tanggal 27 Juli 2015. 